THE INFLUENCE OF L1 TOWARD STUDENTS' WRITING SKILL

\title{
ROZI SETIAWAN
}

Universitas Pendidikan Indonesia

\begin{abstract}
Indonesian students who learn English as a Foreign Language (EFL) often find it difficult to produce ideal texts. It might be caused by their limited vocabulary and the lack of grammar insight. One of the research findings shows that the different structure between $L 1$ (first language) and TL (target language) might also contribute to this matter. Regarding these issues, this study aims to find out the significant difference of the use of L1 and TL toward students' writing skill. Furthermore, this study also tries to seek the challenges that the teacher faced in employing L1 and TL as language instructions in the classroom. This study employed Mixed-Method research in which the data obtained would be analyzed quantitatively and qualitatively. Tests and interview were employed as instruments in which both of them would be analyzed quantitatively and qualitatively as well. The sample of this research was 44 students at grade ten of a Senior High School in West Nusa Tenggara. The sampling technique employed was purposive sampling. The results showed that there was the significant difference of the use of L1 and TL toward students' writing skill. It was indicated after testing the null hypothesis by employing t-test (2.413) which is higher than t-table (2.018) at a confident level .05 (95\%) with a degree of freedom (df) 42. Furthermore, from the interview with the teacher, it was shown that the English teacher's main challenge in employing L1 and TL was on the limited time allocation to explain materials in bilingual way.

KEYWORDS: First Language, Target Language \& Writing Skill
\end{abstract}

Received: Mar 15, 2018; Accepted: Apr 05, 2018; Published: Apr 28, 2018; Paper Id.: IJESRJUN20185

\section{INTRODUCTION}

Writing is categorized as one of the productive skills which requires an ability to tie up the words to become a sentence, to bind up sentences become a coherent paragraph, and to combine the coherent paragraphs into text. In Indonesian EFL classroom, since coming to the first grade of Junior High School students have been introduced to the four basic skills of English. Those skills are listening, speaking, reading, and writing. Since 2004, Genre-Based Approach has become the main approach in Indonesian National Curriculum. This approach employs various text types such as descriptive, procedure, recount, narrative, and report for Junior High School (Kemendikbud, 2013 in PP No. 68 Tahun 2013). Meanwhile Kemendikbud (2013) in PP No. 69 Tahun 2013, states that for Senior High School the type of texts provided by the government are narrative, recount, procedure, report, analytical exposition, hortatory exposition, explanation, descriptive, discussion, news item, review, anecdote, and spoof.

Students who learn EFL in the classroom often find it difficult to produce a good text. It might be caused by the limited vocabulary and limited exposure toward the target language. Ariyanti (2016) states that the most fundamental problem that is faced by students of EFL in writing is the different structure and grammar between the first language (Bahasa Indonesia) and the target language (English) and their capability in translating their first 
language into the target language. Furthermore, Afrilyasanti et al. (2016) state that the commonest problem of students in writing is the limited ideas resulted from difficulties in finding the words and also the grammar. Moreover, Rahmatunisa (2014) states that the most bothering aspects of linguistics and cognitive category are grammar and developing the idea. Thus, it can be simplified that the most classical problems faced by Indonesian EFL students are the lack of grammar and difficulties in developing ideas. As Afriyanti (2016) states that the problems might have resulted from the different structure and grammar between the first (L1) and the target language, it could be better if L1 is used to cope these difficulties.

The role of language in the classroom is very essential, especially when talking about EFL. Limited exposure towards the target language (TL) might become the biggest barrier to mastering English. Hence, the idea of using the first language (L1) to accelerate the TL mastery appeared in the last decades. Weschler (1997) states that although the adult learners make a big effort, it looks impossible to omit their first language impact toward their target language. Mostly, they employ such a translation strategy to crack the input coming. If teachers do not pay sufficient attention and keep employing full target language in the classroom, it might trigger the students' affective filters. (Krashen, 1987). Moreover, in Indonesian classroom, English is placed as one of the primary subjects besides science and mathematics. However, the limited time allocated for the subject and the lack of exposure toward English in their daily life cause the students to have low productive skills, especially in writing. Related to these two issues; the use of L1 in EFL classroom and students' low writing skill, a study regarding the use of L1 in EFL classroom would be conducted. This is a combination of quantitative and qualitative research in which is aimed at finding the difference between the two groups employed different kinds of language instructions, English and Bahasa Indonesia. Another aim was to find out the challenges that the teacher encountered in employing L1 and TL as language instruction.

This study was limited to finding out the significant difference of the employment of First Language (Bahasa Indonesia) and Target Language (English) on students' writing skill. It also aimed to find out the difficulties of employing L1 and TL in teaching writing. The text used in the study was descriptive text. Furthermore, the subject of the study is the students of grade ten in a High School in West Nusa Tenggara. In addition, the findings, discussion, and conclusion were drawn from the analysis of the data which were obtained from students and teacher.

The result of the study was intended to give additional information for students, teachers, and future researchers. For students, it was expected to improve their writing skill, while for teachers this study aimed to increase their insight on how to employ proper strategies to cope students' difficulties in productive skills, especially in writing. Furthermore, this study was also intended to give reflection to English teachers on how to make use of L1 in teaching English. Moreover, for future researchers, it was expected to be sources of information when similar kind of study is conducted.

There are two research questions employed in this research, those are as follows:

- Is there any significant difference between the use of TL and L1 toward students' writing skill?

- What are the challenges in using TL and L1 in the classroom that the English teachers face?

In this study, the researcher tried to answer the first research question quantitatively by employing the following hypothesis: 
- Alternate Hypothesis (Ha): There is a significant difference between the use of L1 and TL toward students' writing skill.

- Null Hypothesis (H0): There is no significant difference between the use of L1 and TL toward students' writing skill.

\section{DESCRIPTIVE TEXT}

One of the text genres which is taught in Indonesian Senior High School is descriptive text. Describing is said as one of the first skills which most language users firstly learn (Knapp and Watkins, 2005). Furthermore, according to Knapp and Watkins (2005), descriptive is a text which consists of two parts namely classification and description. Meanwhile, Wardiman et al. (2008) define descriptive text as a part of factual genres which has the purpose to describe a person, place or particular thing. The genre of describing can also be used to write any kinds of texts such as information reports, literary descriptions, descriptive recounts, etc. (Knapp and Watkins, 2005).

Descriptive text is constructed by two compartments namely identification and description. Identification is where the specific participants such as the person, animal, or thing are identified. Meanwhile, description is the larger scope where a specific participant in identification is described extensively. Besides, Knapp and Watkins (2005) also describe grammatical features which are mainly found in the descriptive text as follows:

- Mainly use the present tense to describe things from a factual point of view.

- Dominantly use relational verbs (e.g. is, are, has, have) to classify and to describe qualities and functions of things or phenomena.

- Mainly use action verbs to describe behavior or attitude of the specific participants.

- Use action verbs in the metaphoric way to create literary and common-sense descriptions.

- Use mental verbs to describe the feeling in literary descriptions.

- Use an adjective to add additional information to a noun.

- A detailed description of the verb is usually added by employing proper adverbs.

The employment of L1 in teaching foreign language might be more beneficial since the students employ their mother tongue to acquire the target language. Some research which were conducted show that the employment of L1 might give positive feedback toward the learners. As Chiou (2014) found that the use of L1 in the classroom can facilitate and accelerate students' learning. However, when they are forced to use the target language (TL) all the time, they might have learning difficulties especially for low achiever students. Yet, the medium to convey instruction is really essential. If teachers do not pay attention toward this matter, there will be no acquisition happens. In line with this, Al-Nofaie (2010) further concludes in his research that the low achiever's students tended to be exposed more to the first language (Arabic) when they learn the foreign language (English). It aims to get them understand the new language they learn. Furthermore, the students' main interest is being treated by using Arabic in exam instruction, translating words, comparing two languages, learning grammar, asking questions, and participating in pair work. Moreover, a research conducted in Turkish classroom by Sali (2014) shows that three EFL teachers mostly employed L1 to serve three major functions, those are academic, managerial, and socio-cultural. In academic, teachers make use of L1 to convey the content of the lesson, 
while in managerial teachers' purpose to employ L1 is to rule the classroom interactions and how to manage the teaching and learning process. Meanwhile, in socio-cultural context, the aim of L1 employment is to establish rapport among students in the classroom. Hence, the use of L1 in EFL classroom can be beneficial either for teachers or for students.

\section{L1 INSTRUCTION TO TEACH ENGLISH}

The employment of L1 in teaching English has been said effective (Chiou, 2014; Al-Nofaie, 2010; Sali, 2014). The role of L1 can take place as language instruction in which most of the foreign language learners need. As Faltis (1990) mentions that teachers can make use of L1 by employing various techniques or methods such as New Concurrent Method in which there is a balance between the use of L1 and L2 in language teaching. Teachers might use code-switching to create systematic and purposeful learning for students. In addition, there are four areas of code-switching that can be employed such as presenting concepts, reviewing the previous lesson, attracting learners' attention, and rewarding students. Besides code-switching, there are some similar techniques which employ the connection between L1 and L2, those are Bilingual Method and Reciprocal Method which allow the students to move from using L2 to L1 or vice versa (Dodson, 1967; Hawkins, 1987 in Al-Nofaie, 2010).

The position of L1 in EFL classroom is not as the dominant language which might decrease the exposure of the target language (TL). However, it might be useful cognitive, effective, and linguistic tools for the development of TL (Atkinson,1987; Auerbach,1993; Canagarajah,1995; Cummins, 2007; Elridge, 1996; Ferguson, 2003; Qian, Tian, \& Wang, 2009; Rivera, 1990; Rivers, 2011; Shamash, 1990 in Sali, 2014). Thus, the use of L1 in FLT must be employed in a proper way to get the students' main purpose, to make them able to communicate using the TL. In line with this, Cummins in his Threshold Hypothesis (1979) explains that an individual mastery level in L2 is determined by his/her mastery of his native language. Moreover, Cummins (2000) also states that language instruction which is given in L1 does not create a harmful effect in the TL development. However, it might create the positive effect.

\section{PREVIOUS RELATED RESEARCHES}

There have been some previous researchers conducted to find out the influence of L1 towards the target language. The first research was conducted by Yigzaw (2012) about the impact of L1 in L2 English writing classes. It used experimental study by employing L1 use in pre-writing stage. The participants in this study were 108 students (56 students from the experimental group and 52 students from the control group). Besides analyzing the data quantitatively by employing t-test, the interview was also done to find out students' reflection regarding the employment of L1 in the teaching and learning process. The treatments were given during one and half month. The result of the study showed that the experimental group scored higher than the control group due to post-test results. Moreover, from the interview, most participants preferred to use L1 for developing the idea in pre-writing stage. Hence, the employment of L1 in pre-writing stage helped them construct better writing in L2.

The next research was conducted by Dweik and Al Hommos (2007) entitled the effect of Arabic proficiency on the English writing of bilingual Jordanian Students. It was a correlation study. This study employed composition prompt test in which the participants were asked to write two different texts in Arabic and English. The sample was 20 students at the intermediate level performance of English in Jordan public schools. The results show that the Arabic composition (writing in Arabic) had the same correlation ( $\mathrm{r}=0.581)$ with the English composition. It means that students who got a high mark in Arabic also obtained very close mark in English. 
The third research was conducted by Lemsara (2015). The study aimed at finding out whether or not there is the influence of learners' first language on their writing. The sample was 40 English Department students in the first year at University of BISKRA. Instruments employed in this study were the questionnaire and students' writing. There were 40 questionnaires and 27 students' writing sample which were analyzed. The results from questionnaires show that most students got no difficulties in writing. However, their writing shows that they have some problems regarding linguistics competence and difficulties in developing the idea. Hence, it was concluded that the EFL learners tend to go back to their L1 when they need to produce writing in TL due to the limited competence in acquiring TL. In addition, the influence of L1 might be diminished as students acquire TL.

\section{METHOD}

\section{Research Design}

This study employed the quantitative and qualitative research design (mixed-method). Mixed-method means putting quantitative data and qualitative data together (Hamied, 2017). Furthermore, Miles and Huberman as cited in Creswell (2012) state that the use of mixed-method design aims to create a powerful mix. Quantitatively, the participants were put into two groups: experimental group and control group. The experimental group was treated by using L1 and TL (combined), meanwhile, the control group was treated by using full TL. The main focus of this study was on the language instruction used by the teacher in the classroom. Meanwhile, qualitatively, the data was gained through in-depth interview with the teacher about her teaching experience during giving the treatments.

\section{Data Collection}

Sample

The participants in this study were 44 students who are in the grade ten of a State Senior High School in West Nusa Tenggara. They were selected purposively based on the assumption that they are all the native speakers of Bahasa Indonesia and they have never studied abroad. Purposive sampling is a sampling technique which is made based on considering some characteristics of the population (Arikunto, 2010). The participants of the study were between 16-18 years old. They have studied English as the compulsory subject for almost 4 years, beginning from the first grade of Junior High School. They almost employed their first language in their everyday life and English is merely used for an academic purpose, mostly in the classroom.

\section{Instruments}

There were three kinds of instruments employed in this study. The first one was pre-test. The pre-test was administered to the students in order to identify their ability (low, middle, or high achiever) before conducting the treatments. The students were asked to write a descriptive text either about the person, animals, or things. The second instrument was post-test, it was distributed after conducting the treatment. The pre-test was about "one of the tourism objects in my region”. Meanwhile, yhe post-test aimed at assessing the participants' performance in both groups. The third instrument was an interview. The semi-structured interview consists of 10 questions in which the first two questions were intended to gain the general information about the teacher, while the rest of questions were aimed to find out the challenges and situation that the teachers in the classroom faced while employing Bahasa Indonesia and English as the language instruction. 


\section{Data Collection Procedure}

In finding out the difference between the two groups, different language instructions were administered to both groups, experimental group (L1) and control group (TL). The study was conducted on April 2017 during three weeks or 6 meeting. First, each group would be given pre-test in the first meeting to identify their strengths and weaknesses in writing. A technique which was employed by the teacher was PPP (Presentation-Practice-Production). It was the commonest technique which the teacher employed in the classroom. For the experimental group, the language instruction and explanation mostly would be delivered in L1 combined with TL. Meanwhile, for control group language instruction and explanation would be delivered in full TL. In the first three meetings, the teacher would give different kinds of genres of descriptive: human, animal, and things. In Presentation phase, the teacher would explain about common features of descriptive text including generic structure, social functions, grammatical features, etc. While in Practice phase, students would be given chance to create their text. Furthermore, in this phase teacher might help and guide the students. They may work together with their friends, and also they may use a dictionary. In the production phase, students would create their own text without any help. In the last meeting, students would produce descriptive text related to a topic "a tourism object in my region".

\section{Data Analysis Technique}

Quantitative data were gathered from students' scores from the two groups in pre-test and post-test. The students' writing would be assessed by using a scoring rubric which was adopted from Brown (2007). Scoring rubric becomes very essential in assessing writing since it can be categorized as a subjective test, as Hughes (2003) states that subjective test involves personal judgement of the assessor. There were five aspects to be assessed by employing this rubric such as content (30\%), organization (20\%), grammar (20\%), vocabulary (15\%), and mechanic (15\%). Each aspect would be scored from 1 to 4 (weak-strong). Thus, the maximum score that the students would get is 100 . Having given the grades for the result of students writing, the researcher inserted the students' scores into the table data. The researcher further found the mean deviation score of pre-test and post-test by using the formula below :

The formula of the mean score for the experimental group:

$$
M x=\frac{\sum d x}{N}
$$

The formula of the mean score for control group:

$$
M y=\frac{\Sigma d y}{N}
$$

$$
\begin{aligned}
& \text { Mx } \quad \text { : The mean score of experimental group } \\
& \text { My } \quad \text { : The mean score of control group } \\
& \Sigma \mathrm{dx} \quad: \text { The sum of deviation score of pre-test and post-test of experimental group } \\
& \Sigma \text { dy } \quad: \text { The sum of deviation score of pre-test and post-test of control group } \\
& \mathrm{N} \quad: \text { Number of sample }
\end{aligned}
$$

The next step was calculating the square deviation by using the following formula : 
Here is the square mean deviation of experimental group:

$$
\sum X^{2}=\sum d x^{2}-\frac{\left(\sum d x\right)^{2}}{N}
$$

Meanwhile, here is the square deviation of control group:

$$
\sum Y^{2}=\Sigma d y^{2}-\frac{(\Sigma d y)^{2}}{N}
$$

Then the correlation coefficients of the two mean scores was calculated to see whether they are seen as significant or not, the formula is below :

$$
t-\operatorname{tes} t=\frac{M x-M y}{\sqrt{\left(\frac{\sum X^{2}+\Sigma Y^{2}}{N x+N y-2}\right)\left(\frac{1}{N x}+\frac{1}{N y}\right)}}
$$

In which,

t-test : The degree of differences

Mx : The mean score of experimental group

My : The mean score of control group

Nx : The number of sample of experimental group

Ny : The number of sample of control group(Arikunto, 2006)

The last step was to count the degree of freedom in which the following formula was employed:

$\mathrm{df}=\mathrm{Nx}+\mathrm{Ny}-2($ Arikunto, 2006)

After obtaining the result of t-test, then it is tested at the significant levels.05 (95\%). The result of the test could be interpreted by using the following formula :

- $\quad$ If $\mathrm{t}$-test $\geq \mathrm{t}$-table at the significant level.05, $\mathrm{H}_{0}$ is rejected.

- If $\mathrm{t}$-test $<\mathrm{t}$-table at the confidence level.05, $\mathrm{H}_{0}$ is failed to be rejected.

Furthermore, the data gained from the semi-structured interview would be analyzed based on Creswell (2012) five-step required in interpreting the findings:

- $\quad$ Organizing data is the phase where the researcher organized the data by recording the interview.

- Transcribing data is the second step where the data had already been organized and transcribed. Transcription is the process of converting the audio form into written form.

- Coding the data is the process of grouping and labeling text to form descriptions and broad themes. The transcription would be read carefully to find the major themes in which it would be related to research questions.

- Representing the findings means to find out the major themes that had been written in form of findings would be 
split into sub -themes and would be written in narrative form.

- Interpreting the findings means the findings that have been written in form of the narrative were explained in the meaning of research. This explanation involved advancing personal views, comparing and contrasting between the findings and the literature, and suggesting limitation and future research.

\section{RESULTS}

\section{The Result of Pre-Test and Post-Test to Test Null Hypothesis}

The data were collected from students' pre-test and post-test scores and also from a semi-structured interview with the teacher. The following table 1 shows the result of pre-test and post-test from experimental group and control group:

Table 1: Descriptive Statistics between Pre-Test and Post-Test of Experimental Group and Control Group

\begin{tabular}{|c|c|c|c|c|}
\hline Test & Group & N & Mean & SD \\
\hline \multirow{2}{*}{ Pre-test } & Experimental & 22 & 65.227 & 5.984060719 \\
\cline { 2 - 5 } & Control & 22 & 65.625 & 5.084845599 \\
\hline \multirow{2}{*}{ Post-test } & Experimental & 22 & 72.5 & 9.20985497 \\
\cline { 2 - 5 } & Control & 22 & 66.931 & 6.096047616 \\
\hline
\end{tabular}

In the table above, it can be interpreted that the mean score for the experimental group was 65.227 with standard deviation ( $\mathrm{SD}=5.984)$, while which the control group was 65.625 with standard deviation $(\mathrm{SD}=5.084)$. It can be tentatively said that both groups have the similar stand as the means of pre-test were almost balanced. The means of post-test from the experimental group and control group were 72.5 and 66.931 respectively. Meanwhile, the standard deviation (SD) of both groups was 9.209 and 6.096 respectively. Furthermore, the standard deviation in post-test from both groups rise as the table 1 shows. Moreover, the scores in post-test from both experimental group and control group rise after they had been given treatments as the following Table 2 shows.

Table 2: Minimum and Maximum Scores of Pre-Test and Post-Test Between Experimental Group and Control Group

\begin{tabular}{|l|l|l|l|l|}
\hline Test & Group & N & Max & Min \\
\hline \multirow{2}{*}{ Pre-test } & Experimental & 22 & 82.5 & 55 \\
\cline { 2 - 5 } & Control & 22 & 78.75 & 58.75 \\
\hline \multirow{2}{*}{ Post-test } & Experimental & 22 & 87.5 & 61.25 \\
\cline { 2 - 5 } & Control & 22 & 78.75 & 61.25 \\
\hline
\end{tabular}

The minimum scores that the students got in pre-test were 55 and 58.75 for experimental group and control group respectively. Meanwhile, after having been given treatment, the minimum scores of experimental group and control group improved in post-test, they were 61.25 for both groups. Furthermore, the maximum scores got by experimental group and control group in pre-test were 82.5 and 87.5 respectively. Meanwhile, after conducting post-test, the maximum scores in experimental group improved to 87.5, however, the maximum scores in control group remained steady in 78.5 . From these rough description, it can be said that the treatments that were given to both groups affect their writing skill as the minimum scores in post-test were higher than which in the pre-test. Moreover, the maximum scores in experimental group improved, so it can be said that there was an effect of treatments giving in this group.

After distributing the scores of pre-test and post-test, the deviation scores of pre-test and post-test in experimental 
group and control group were retrieved. It could be seen in the following tables. Table 3 shows the deviation scores and square deviation scores of experimental group and control group. Meanwhile, table 4 shows the pre-test and post-test scores with total deviation scores and total square deviation scores of the control group.

Table 3: Total Deviation Scores and Total Square Deviation Scores of Experimental Group

\begin{tabular}{|c|c|c|c|c|}
\hline $\begin{array}{c}\text { Total } \\
\text { Participants }\end{array}$ & $\begin{array}{c}\text { Total Pre- } \\
\text { Test Scores } \\
(\mathbf{\Sigma} 1)\end{array}$ & $\begin{array}{c}\text { Total Post- } \\
\text { Test Scores } \\
(\mathbf{\Sigma} 2)\end{array}$ & $\begin{array}{c}\text { Total Deviation Scores } \\
\text { of Pre-Test and Post- } \\
\text { Test }(\mathbf{\Sigma} \mathbf{d x})\end{array}$ & $\begin{array}{c}\text { Total of Square } \\
\text { Deviation Scores } \\
\left(\mathbf{\Sigma} \mathbf{d} \mathbf{2}^{2}\right)\end{array}$ \\
\hline $\mathbf{2 2}$ & 1435 & 1595 & 160 & 2996.875 \\
\hline
\end{tabular}

Table 4: Total Deviation Scores and Total Square Deviation Scores of Experimental Group

\begin{tabular}{|c|c|c|c|c|}
\hline $\begin{array}{c}\text { Total } \\
\text { Participants }\end{array}$ & $\begin{array}{c}\text { Total Pre-Test } \\
\text { Scores } \\
(\mathbf{\Sigma} 1)\end{array}$ & $\begin{array}{c}\text { Total Post- } \\
\text { Test Scores } \\
(\mathbf{\Sigma} \mathbf{2})\end{array}$ & $\begin{array}{c}\text { Total Deviation Scores of } \\
\text { Pre-Test and Post-Test } \\
(\Sigma \mathbf{d y})\end{array}$ & $\begin{array}{c}\text { Total of Square } \\
\text { Deviation Scores } \\
\left(\Sigma \mathbf{d y}^{\mathbf{2}}\right)\end{array}$ \\
\hline $\mathbf{2 2}$ & 1443.5 & 1472.5 & 28.75 & 1029.687 \\
\hline
\end{tabular}

In table 3 it shows that the total deviation scores of pre-test and post-test for experimental group were 160 and the total of square deviation scores were 2996.875. Meanwhile, Table 4 shows the total deviation scores of pre-test and posttest and total square deviation scores for the control group, they were 28.75 and 1029.687 respectively. After that, the mean deviation square (M) was computed for the experimental group (Mx) and control group (My). The sum of square deviation scores for both groups $\left(\Sigma \mathrm{dx}^{2}\right.$ and $\Sigma \mathrm{dy}^{2)}$ was also being computed. After doing the computation, it was got that the mean deviation square for the experimental group (Mx) was 7.272, while the mean deviation square for the control group (My) was 1.306. The next step was calculating the square mean deviation for both groups $\left(\Sigma \mathrm{X}^{2}\right.$ and $\left.\Sigma \mathrm{Y}^{2}\right)$. It was got that the square mean deviation for the experimental group was 1833.239 and the square mean deviation for the control group was 992.116.

The next step was to find t-count by employing t-test formula. In this formula, the mean deviation square (Mx and My), the mean square deviation from both groups $\left(\Sigma \mathrm{X}^{2}\right.$ and $\left.\Sigma \mathrm{Y}^{2}\right)$, and the number of samples were employed to get the $\mathrm{t}$ count. The result of this computation was 2.413. Furthermore, after computing t-count by employing t-test formula, the last step was to test the hypothesis. It could be retrieved by comparing t-test result with t-table with a degree of freedom (df) 42. In addition, the two-tailed test at a confident level.05 (95) was employed in the comparison of t-test result and t-table. The comparison can be seen in the following Table 5.

Table 5: Testing the Hypothesis

\begin{tabular}{|c|c|c|}
\hline \multirow{2}{*}{ t-test } & \multicolumn{2}{|c|}{ t-table } \\
\cline { 2 - 3 } & degree of freedom $(\mathbf{d f})$ & confident level (.05) \\
\hline $\mathbf{2 . 4 1 3}$ & 42 & 2.018 \\
\hline
\end{tabular}

Table 5 shows that t-test result is higher than $\mathrm{t}$-table 2.018. It indicates that the null hypothesis $\left(\mathrm{H}_{0}\right)$ is rejected. Thus, there is the significant difference between the use of L1 and TL toward students' writing skill.

\section{Teacher's View about the Employment of L1 and TL during Teaching and Learning Process}

There were ten questions addressed to the teacher who was involved in teaching and learning process. The questions mostly about her view about the employment of L1 and TL as language instructions in the classroom. She stated that students during the session found it helpful to understand the materials. When teacher explained materials in 
the target language (TL) without translating or explaining the Indonesian version, there were some parts of the materials that the student might miss. The parts that the students might miss were usually related to new things they just had heard. Mostly, the things were related to grammar and structure.

The employment of either L1 or TL in the classroom has strengths and weaknesses. The strength of the use of L1 is that the teacher does not need much time to spend in order to make the students understand, meanwhile the strength of employing full TL is that the students feel being challenged to improve their English, especially their productive skills. Moreover, they would try hard to understand the foreign language by equipping themselves with a dictionary or asking directly to the teacher when there is something that is difficult to understand. Besides strengths, the employment of L1 or TL also has weaknesses. The weaknesses of employing L1 could demotivate the students to improve their English. They would become effortless to seek something new about English. It might be caused by the deliverance of material in their mother tongue with full L1. Moreover, it does not only happen in L1, the employment of full TL also requires much more time since most students do not understand English that might be caused by limited exposure to this language. In addition, the use of only English in the classroom during English session 2 times a week might contribute to this weakness.

Finally, the teacher concluded that each of this language instruction has its own strengths and weaknesses. So, by combining both of them together might ease the teacher in delivering the materials. Furthermore, it might be beneficial for students also because most of them have limited exposure toward the target language in which this situation might bring difficulties to them in understanding both spoken and written English. Moreover, the teacher also stated that the class where L1 and TL (combined) employed had more significant improvement than the class employed full TL. However, the employment of mix language instructions requires much time since the teacher sometimes translate what they explained in TL into L1. The teacher tried quite hard to keep employing English because she wanted to expose the TL more to the students.

\section{DISCUSSIONS}

After testing the hypothesis, it could be concluded that the employment of L1 and TL (combined) might promote students' writing skill. The t-test revealed that there was significantly different between the two groups, the higher improvement shows by the experimental group. It is in line with research finding of Yigzaw (2012) that showed that experimental group which was treated by using L1 in pre-writing stage scored higher than those from the control group. It is because the teacher's use of L1 in pre-writing stage might provide a clear understanding for students rather than employing full TL that might create misunderstanding for them. He also emphasizes that the use of L1 in pre-writing stage would respectfully encourage students in developing the idea and setting the goals which might not be found in the classroom which fully employ L2.

The findings of this study also correspond with the finding of a research conducted by Dweik and Al Hommos (2007) which resulted that there was a significant relationship between the fluency of Arabic (L1) and their ability in writing in English (TL). The higher their score in Arabic writing, the closer similar score they got in English writing. In addition, Perkins (1988) states that the beginner writer of the first language may produce poor foreign language writing even vice versa. It might be affected by insufficient knowledge of the target language. Shortly, the ability to write in the first language have big contribution toward writing production in the foreign language, especially when the two languages 
have some similarities in common.

The higher mean scores of an experimental group can also be interpreted as those who involved in this group have larger chance to share their understanding in L1 rather than those in control group who were treated by using full TL. In teaching material that the learners might be difficult to understand, the teacher might employ L1. As Cianflone (2009) stresses out that teachers might use L1 in teaching grammar, vocabulary (word formation), and difficult concept of broad comprehension. The similar strategy was also used by Liu et al. (2004) and Forman (2010, 2012). Liu et al. (2004) who taught English in a High School in Korea frequently made use of L1 to teach difficult grammar and vocabulary. Meanwhile, Forman $(2010,2012)$ who did a study to 9 English teachers in Thai university found out that the teachers employed L1 to deliver information about sound, grammar, meaning, and the culture of foreign countries. So, the employment of L1 may help promote the L2 acquisition.

However, most students' in both experimental and control group got low scores in the last three aspects assessed in their writing: vocabulary, grammar, and mechanics. It might be t result of their lack of English mastery that is resulted from the limited lexicon they have, the lack of grammar knowledge, and the lack of mechanic which might be caused by the vocabulary mastery. It can be seen from the recurring problem in their word spelling. This phenomenon corresponds with Cummins (1979) who says that bilingual children may have the advantage to have positive transfer effect from L1 to TL. This effect can be attained by the children when they have already had enough vocabulary or lexicon stock which will provide larger diction when they do encoding and decoding process. Thus, it is essential for teachers to encourage the students' to enrich their vocabulary. Teachers might employ various strategies to facilitate the encouragement.

Teacher's view about the employment of L1 as the language instructions which states that students might miss some important parts of the teaching and learning when foreign language (TL) is used all the time. This statement also corresponds with Chiou (2014) who states that if the low achievers are exposed to TL all the time, they might get difficulties in maximizing their learning. As consequence, teachers have to be able to provide a suitable medium of instruction to get this maximum learning. Unless this matter does enough immersion by the teacher, the acquisition of TL would not be running well. Besides, the teacher also stated that there was still a problem existed regarding the employment of L1 combined with TL in the classroom. The problem is related to the time would be spent by the teacher when she employed bilingual instruction. However, a teacher has to take into account that the low achiever students need a clear explanation so that they will not be left behind (Al-Nofaie, 2010).

\section{CONCLUSIONS}

This research employed quantitative research and qualitative research altogether. Quantitatively, the research results show that there was the significant difference of the use of L1 and TL toward students' writing skill. It was indicated after testing the null hypothesis by employing t-test (2.413) which is higher than t-table (2.018) at the confident level.05 (95\%) with a degree of freedom (df) 42. Meanwhile, qualitative data analysis results show that English teacher's main challenge in employing L1 and TL was on the time needed to explain materials in both languages.

It is expected that in the future there will be some large-scale research about the make use of L1 in EFL classroom settings. Since students in Indonesian classroom are foreign language learners, they need proper strategies in coping problems related to acquiring the foreign language. For teachers who teach in the classroom with a large number of low achiever students, they can use the combination of L1 and TL when teaching complex contents such as grammar, 
vocabulary, and comprehension.

\section{ACKNOWLEDGEMENT}

I would like to deliver my gratitude to the school officials for giving a permit to conduct this research and especially for the English teacher who kindly spared her time for this research being conducted. This article is also fully supported by Indonesia Endowment Fund for Education (LPDP) Scholarship.

\section{REFERENCES}

1. Al-Nofaie, H. (2010). The Attitude of Teachers and Students towards Using Arabic in EFL Classrooms in Saudi Public Schools-A Case Study. Novitas-Royal (Research on Youth and Language), 4 (1), pp. 64-95.

2. Afriyasanti et al. (2016). Effect of Flipped Classroom Model on Indonesian EFL Students' Writing Ability Across and Individual Differences in Learning. International Journal of English Language and Linguistics Research, 4 (5), pp. 65-81.

3. Arikunto, S. (2006). Prosedur Penelitian Suatu Pendekatan Praktik. Jakarta: Rineka Cipta.

4. Arikunto, S. (2010). Prosedur Penelitian: Suatu Pendekatan Praktis, edisi revisi 2010. Jakarta: Rineka Cipta.

5. Ariyanti.(2016). The Teaching of EFL Writing in Indonesia. Dinamika Ilmu, 16 (2), pp. 263-277.

6. Brown, J. D. (2007). Multiple views of L1 writing score reliability. Second Language Studies, 25 (2), pp. 1-31.

7. Chiou, B. (2014). Rethinking the Role of L1 in EFL Classroom. Journal of English Teaching and Learning, 38 (4), pp. 53-78.

8. Cianflone, E. (2009). L1 use in English courses at university level, a survey of literature on students and teachers' perspectives. Retrieved from

http://www.esp-world.info/Articles_22/PDF/L1\%20use\%20in\%20English\%20Courses\%20at\%20University\%20Level.pdf

9. Creswell, J. W. (2012). Educational Research: Planning, Conducting and Evaluating Quantitative and Qualitative Research Fouth Edition. Boston: Pearson.

10. Cummins, J. (1979). Linguistic interdependence and the educational development of bilingual children. Review of Educational Research, 49, 222-251.

11. Cummins, J. (2000). Language, power, and pedagogy: Bilingual children in the crossfire. Clevedon, UK: Multilingual Matters.

12. Nooriafshar, Mehryar. "A Practical Approach To Learning The Basics of Writing In Japanese."

13. Dweik, B. S. \& Al Hommos, M. D. A. (2007). The Effect of Arabic Proficiency on The English Writing of Bilingual Jordanian Students. Retrieved from http://files.eric.ed.gov/fulltext/ED497505.pdf.

14. Faltis, C., 1990. New directions in bilingual research design: the study of interactive decision making. In Jacobson, R. and Faltis, C., ed. Language distribution issues in bilingual schooling. Clevedon: Multilingual matters, 45-57.

15. Forman, R. (2010). Ten principles of bilingual pedagogy in EFL. In A. Mahboob (Ed.), The NNEST Lens: Non native English speakers in TESOL (pp. 54-86). UK: Cambridge Scholars Publishing.

16. Hamidou-Lachachi, Feryal Choukria. Assessing the Writing Skill in an ESP Context: the case of 1st Year Master Students at the Department of Biology. Diss. 2016.

17. Forman, R. (2012). Six functions of bilingual EFL teacher talk: animating, translating, explaining, creating, prompting and dialoguing. RELC Journal, 43(2), pp. 239-253. 
18. Hamied, F. A. (2017). Research Methods: A Guide for First Time Researchers. Bandung: UPI Press.

19. Hughes, A. (2003). Testing for Language Teachers. Cambridge : Cambridge University Press.

20. Krashen, S. D. (1987). Principles and practice in second language acquisition. New York: Prentice Hall.

21. Kemendikbud. (2013). Peraturan Menteri Pendidikan dan Kebudayaan Republik Indonesia Nomor 68 tahun 2013 tentang Kerangka Dasar dan Struktur Kurikulum Sekolah Menegah Pertama/Madrasah Tsanawiyah. Jakarta: Kemendikbud.

22. Kemendikbud. (2013). Peraturan Menteri Pendidikan dan Kebudayaan Republik Indonesia Nomor 69 tahun 2013 tentang Kerangka Dasar dan Struktur Kurikulum Sekolah Menegah Atas/Madrasah Aliyah. Jakarta: Kemendikbud.

23. Knapp, P. and Watkins, M. (2005). Genre, Text, grammar: Technologies for Teaching and Assessing Writing. Sydney: University of New South Wales Ltd.

24. Liu, D. et al. (2004). South Korean high school English teachers' code-switching: questions and challenges in the drive for maximal use of English in teaching. Tesol Quarterly, 38(4), pp. 605-638.

25. Perkins, K. (1988) First and second language reading comprehension. Unpublished manuscript. ERIC Document Reproduction Service No. ED. 304-875.

26. Rahmatunisa, W. (2014). Problems Faced by Indonesian EFL Learners in Writing Argumentative Essay. English Review: Journal of English Education, 3 (1), pp. 41-49.

27. Sali, P. (2014). An analysis of teachers' use of L1 in Turkish EFL classrooms. Elsevier: System 42, pp. 308-318.

28. Wardiman, et al. (2008). English in Focus: for Grade VII Junior High School (SMP/MTs). Jakarta: Pusat Perbukuan Depdiknas.

29. Weschler, R. (1997). Uses of Japanese (L1) in the English classroom: Introducing the functional-translation method. The Internet TESL Journal, 3(11). Retrieved from http://iteslj.org/Articles/Weschler-UsingL1.html.

30. Yigzaw, A. (2012). Impact of L1 Use in L2 English Writing Classes. Ethiopia Journal of Education and Science, 8 (1), pp. 11 27. 
